\title{
GREEN SYNTHESIS, ANTIMICROBIAL AND ANTICANCER ACTIVITIES OF AgNPS PREPARED FROM THE LEAF EXTRACT OF Eucalyptus camaldulensis
}

Yunus ÇETINTAŞ*, Ula Ali Koçman Vocational School, Muğla Sıtkı Koçman University, Turkey, yunuscetintas@mu.edu.tr

(iD) https://orcid.org/0000-0001-6707-6112)

Said NADEEM, Köşk Vocational School, Aydın Adnan Menderes University, Turkey, said.nadeem@adu.edu.tr

(iD https://orcid.org/0000-0001-5025-9326)

Esin SAKALLI ÇETIN, Faculty of Medicine, Muğla Sitkı Koçman University, Turkey, esincetin@mu.edu.tr

(iD) https://orcid.org/0000-0002-9715-1424)

Elif ELIUZ ERDOĞAN, Vocational School of Technical Sciences, Mersin University, Turkey, eliferdogan81@gmail.com

(iD) https://orcid.org/0000-0003-4317-3000)

Mehmet Ali ÖZLER, Faculty of Sciences, Muğla Sıtkı Koçman University, Turkey, aozler@mu.edu.tr

(iD https://orcid.org/0000-0001-7547-0080)

Received: 09.04.2020, Accepted: 22.06.2020

*Corresponding author DOI: $10.22531 /$ muglajsci.714696

\begin{abstract}
Herein we report the green synthesis of silver nanoparticles (EcAgNPs) from water fraction (Ecs), obtained from methanol extract of Eucalyptus camaldulensis at room conditions. UV-vis, HR-TEM and SEM-EDS devices were used to characterize the EcAgNPs. The UV-visible spectrum of EcAgNPs showed surface plasmon resonance peak at $420 \mathrm{~nm}$. HRTEM images showed that the EcAgNPs were spherical with a diameter in the range 3.7-29.6 $\mathrm{nm}$. $\mathrm{Ag}^{+}$ions were reduced to $\mathrm{Ag}^{\circ}$ by phytochemicals in the without adding external reducing agent. The presence of biomolecules in the Ecs was investigated by UPLC-MS/MS that detected gallic acid $(20.26 \pm 0.10 \mathrm{ppb})$ and quercetin $(12.4 \pm 0.08 \mathrm{ppb})$ as major constituents. The antimicrobial activities of Ecs and synthesized EcAgNPs were tested on Escherichia coli, Pseudomonas aeruginosa, Bacillus subtilis, Staphylococcus aureus strains and Candida albicans yeast. Ecs exhibited antimicrobial activity as MIC between 16.2 and $129.3 \mathrm{mg} \mathrm{mL}^{-1}$ while EcAgNP showed MIC between 6.31 and $14.65 \mu \mathrm{mLL}^{-1}$. The cytotoxicity of both Ecs and EcAgNPs on A549, HT29 and MDA-MB-231 cancer cell lines was tested by MTT. EcAgNPs showed more significant anticancer activity on MDA-MB-231, HT29 and A549 cancer cell lines (8.10 $\pm 0.01,5.08 \pm 0.01$ and $\left.18.58 \pm 0.03 \mu \mathrm{g} \mathrm{mL} \mathrm{L}^{-1}\right)$ than Ecs $\left(219.70 \pm 0.73,916.24 \pm 0.67,999.30 \pm 1.86 \mu \mathrm{g} \mathrm{mL} \mathrm{L}^{-1}\right)$ and it should be investigated for use in various therapeutics.
\end{abstract}

Keywords: Antimicrobial, anticancer, Eucalyptus camaldulensis, phenolics, silver nanoparticle, green synthesis

\section{Eucalyptus camaldulensis YAPRAK EKSTRESİNDEN HAZIRLANAN AgNP'LERİN YEŞİL SENTEZİ, ANTIMIKROBIYYAL VE ANTIKANSER AKTIVITELERİ}

\section{Özet}

Eucalyptus camaldulensis'in oda koşullarındaki metanol ekstresi aracılı su fraksiyonu (Ecs) kullanılarak gümüş nanopartiküllerin (EcAgNP'ler) yeșil sentezini sunuyoruz. EcAgNP'leri karakterize etmek için UV-vis, HR-TEM ve SEMEDS cihazları kullanıldı. EcAgNP'lerin UV-visible spektrumu 420 nm'de yüzey plazmon rezonans pikini gösterdi. HR-TEM görüntüleri, EcAgNP'lerin çapının 3.7-29.6 nm aralığında küresel olduğunu gösterdi. Ag+ iyonları, başka indirgeyici madde eklenmeden Ecs'deki fitokimyasallar tarafindan $\mathrm{Ag}^{\circ}$ 'a indirildi. Ecs içindeki biyomoleküllerin varlığı, gallik asit

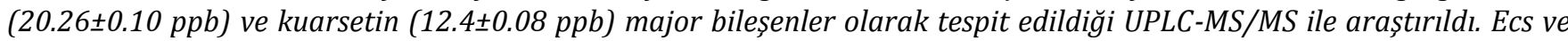
sentezlenmiş EcAgNP'lerin antimikrobiyal aktiviteleri, Escherichia coli, Pseudomonas aeruginosa, Bacillus subtilis, Staphylococcus aureus suşları ve Candida albicans mayası üzerinde test edildi. Ecs, MIC olarak 16.2 ve $129.3 \mathrm{mg} \mathrm{mL-1}$ arasında antimikrobiyal aktivite sergilerken, EcAgNP, 6.31 ve $14.65 \mu \mathrm{g} \mathrm{mL}{ }^{-1}$ arasinda MIC gösterdi. A549, HT29 ve MDAMB-231 kanser hücre hatlarında Ecs ve EcAgNP'lerin sitotoksisitesi, MTT ile test edildi. EcAgNPs MDA-MB-231, HT29 ve

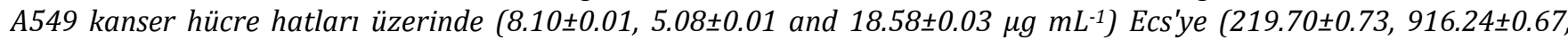
$999.30 \pm 1.86 \mu \mathrm{g} \mathrm{mL}^{-1}$ ) göre daha dikkate değer antikanser aktivite sergilemiştir ve çeşitli terapötiklerde kullanımı için araștırılmalıdır.

Anahtar Kelimeler: Antimikrobiyal, antikanser, Eucalyptus camaldulensis, fenolik, gümüş nanopartikül, yeşil sentez Cite

Çetintaş, Y., Nadeem, S., Sakallı Çetin, E., Eliuz Erdoğan, E., Özler, M.A., (2020). “Green synthesis, antimicrobial and anticancer activities of AgNPs prepared from the leaf extract of eucalyptus camaldulensis", Mugla Journal of Science and Technology, 6(1), 146-155. 


\section{Introduction}

In recent years, nanoscience and nanotechnology have become a popular area of research, mainly concerned with the synthesis, characterization and exploration of nanostructured materials, with considerable effort to replace microsystem processes with nanosystems [1,2] Metallic nanoparticles synthesized to obtain nano-sized biomaterials can be obtained by various approaches such as chemical method, thermal decomposition, electrochemical method, microwave irradiation and laser ablation $[3,4]$. The chemical method is considered to be the simplest method to synthesize silver nanoparticles (AgNPs). However, the use of hazardous chemicals and their harms to the environment limits the use of this method. Due to these drawbacks, researchers are always in search of novel and environment friendly method for the synthesis of nanoparticles [5].

The approaches known as green synthesis in these studies come to the front due to the fact that they do not harm the environment and give economic and rapid results [6]. For the last 10 years, AgNPs have continued to attract researchers attention due to their extensive application in green synthesis [1]. Silver is well known for its potent toxicity to a wide variety of microorganisms and to be a promising antimicrobial material.

AgNPs synthesized using plant extracts with a green synthesis approach offer a safe and environmentally friendly approach. Recently, with the green synthesis approach, AgNPs synthesized from various plants (Tinospora cordifolia [7], Pulicaria glutinosa [8], Thymbra spicata L. var. spicata [9], Ginkgo biloba [10], Ficus krishnae [11], Ficus religiosa [12], Gossypium hirsutum [13], Solanum trilobatum [14], etc.) has been reported to show good antibacterial or anticancer activities. AgNPs have been reported for their antiinflammatory, antiviral, anti-angiogenesis and antithrombocyte activities $[15,16]$.

Eucalyptus camaldulensis Dehnh. is an important medicinal plant of the Myrtaceae family. It has been used as a therapeutic agent in the sore throat diseases and bacterial infections of the respiratory and urinary tract [17]. Studies have shown the antimicrobial activity of the leaf extract and essential oil obtained from $E$. camaldulensis plant $[18,19,20]$. Cineol, cuminal, phellandrene, aromadendral, valeraldehyde, geraniol, cymene, catechol, tannin, terpene, isoprenoid, phenolic, cardiac glycoside, sterol, saponin and flavonoid are some phytochemical components detected in $E$. camaldulensis [19]. In addition to the content analyzes and some biochemical tests $[21,22,23,24]$ on this plant species, not comprehensive research has been conducted on the nanoparticle synthesis and biochemical tests with the green synthesis approach.

In this study, the water fraction from the leaf methanol extract of E. camaldulensis (Ecs) was used as a reducing and stabilizing agent for the synthesis of AgNPs. A previous study on this plant has also reported the green synthesis of AgNPs and their antimicrobial and cytotoxic effects [24]. The formation of the EcAgNPs were initially determined by UV visible spectroscopy. The size, shape, morphology and elemental composition of EcAgNPs were characterized by high resolution transmission electron microscopy (HR-TEM), field emission scanning electron microscopy (FE-SEM) and energy distribution X-ray (EDS) analysis. The presence of biomolecules in the water fraction was determined by ultraperformance liquid chromatography sequential mass spectroscopy (UPLC-MS/MS). The expected phytochemical binding in EcAgNPs synthesis was analyzed by electronic spectroscopy. The antimicrobial activity of Ecs and EcAgNPs against Escherichia coli (ATCC 25922), Pseudomonas aeruginosa (ATCC 27853), Bacillus subtilis (ATCC 6633), Staphylococcus aureus bacterial strains and Candida albicans yeast were tested. Likewise, the cytotoxic effect of Ecs and EcAgNPs on A549 human lung cancer, HT29 human colon cancer and MDA-MB-231 human breast cancer cell lines was tested by MTT.

\section{Materials and Methods}

\subsection{Plant collection and chemicals}

Healthy and mature leaves of E. camaldulensis Dehnh. were collected into a cardboard box from MuğlaMarmaris, Turkey from a sterile way around Gökova area between April and June of 2018. $\mathrm{AgNO}_{3}$ (99\%) was purchased from Merck. All other chemicals were purchased from Sigma-Aldrich with high analytical purity.

\subsubsection{Preparation of plant extracts}

The leaves were washed with cold ultra-pure water to remove the dust and cut into small pieces using waring blender after drying under room conditions and shade. Dry E. camaldulensis leaves were extracted with methanol (3 times; 5 days each). Methanol was evaporated by rotary evaporator (Heidolph Heizbad Hei-Vap, Germany) and the dry extract was stored in a sterile container. $1.25 \mathrm{~g}$ of dried methanol extract was weighed into a $100 \mathrm{~mL}$ volumetric flask and flask was filled with ultra-pure water until the volume became $100 \mathrm{~mL}$. The extract was dissolved in the water using ultrasonic bath for $10 \mathrm{~min}$ and filtered using a $0.20 \mu \mathrm{m}$ membrane disk filter in vacuo. This water fraction (Ecs) was stored at $+4{ }^{\circ} \mathrm{C}$ for further use.

\subsection{Phenolic profile of the aqueous fraction with UPLC-MS/MS}

The Ecs was analyzed to determine the phenolic profile by the UPLC-MS/MS (Xevo TQ-S)[25].

The resulting solution was analyzed by UPLC-MS/MS (Waters Acquity Ultra Performance LC, Xevo TQ-S) using Macherey-Nagel Chromafil Xtra PTFE-20/25 0.20 $\mu \mathrm{m}$ filters. Separation was performed at $40{ }^{\circ} \mathrm{C}$ using the Acquity UPLC BEH C18 column $(1.7 \mu \mathrm{m} 2.1 \times 100 \mathrm{~mm})$. The sample temperature was $10{ }^{\circ} \mathrm{C}$ with an injection volume as $1 \mu \mathrm{L}$. Gradient program was applied in the 
analysis. The mobile phase was used as $\mathrm{H}_{2} \mathrm{O}$ containing $0.5 \% \mathrm{CH}_{3} \mathrm{COOH}$ in the solvent line $\mathrm{A}$ and $\mathrm{MeOH}$ containing $0.5 \% \mathrm{CH}_{3} \mathrm{COOH}$ in the solvent line $\mathrm{B}[26]$.

\subsection{Synthesis of silver nanoparticles (EcAgNPs)}

Ecs $(5.0 \mathrm{~mL})$ was used as the aqueous solution in the EcAgNPs synthesis. The $\mathrm{pH}$ of the fraction was adjusted to 8.0 with $1.0 \mathrm{M} \mathrm{NaHCO}_{3}(0.5-1.0 \mathrm{~mL})$ with Mettler Toledo Seven Multi 8603 Schwerzenbach, Switzerland brand pH meter. $5.0 \mathrm{~mL}$ of Ecs (pH 8.0) and $95.0 \mathrm{~mL}$ of 1 $\mathrm{mM} \mathrm{AgNO}_{3}$ solution were added into a $100 \mathrm{~mL}$ flask. The mixture was allowed to stir for $75 \mathrm{~min}$ at room temperature with the aid of magnetic stirrer. The mixture initially became yellowish green, then transformed into dark red that showed the preparation of EcAgNPs in the solution. The crude solution was centrifuged at $14000 \mathrm{rpm}$ for 30 min that produced the EcAgNPs. The centrifugation was repeated by washing the nanoparticles 3 times with ultra-pure water (Millipore). The obtained EcAgNPs were stored under sterile conditions at $+4{ }^{\circ} \mathrm{C}$ for further studies.

\subsection{Characterization}

Absorbance spectra were obtained using a UV-vis spectrophotometer (Cary 60 Agilent Technologies, Australia) in the wavelengths of 200-800 nm with $1 \mathrm{~nm}$ slit width. The AgNPs synthesis was monitored at intervals of 15 min. HR-TEM (High Resolution Transmission Electron Microscope, $200 \mathrm{kV}$, JEOL JEM 2100F, Japan) was used to determine the size and morphology of AgNPs. The solutions containing AgNPs, dripped separately on copper grid, were air-dried and HR-TEM was applied with $200 \mathrm{kV}$ energy. The surface morphology of the AgNPs was analyzed by the Scanning Electron Microscope (FE-SEM-Field Emission Scanning Electron Microscope, JEOL JSM 7600F, Japan). Elemental analysis of AgNPs was performed with Energy Dispersive X-Ray Spectroscopy (EDS) (Oxford Instruments, UK) in combination with the SEM device.

\subsection{Antimicrobial activity and minimum inhibitory concentration}

\subsubsection{Broth Microdilution Method}

The antimicrobial activity of the Ecs and AgNPs was carried out by Broth microdilution method. E. coli (ATCC 25922), P. aeruginosa (ATCC 27853), B. subtilis (ATCC 6633), $S$. aureus strains of bacteria and $C$. albicans yeast were used in this study. All strains before the test were allowed to incubate for $18-24 \mathrm{~h}$ at $37{ }^{\circ} \mathrm{C}$ after sowing on solid medium (TSA-tryptic soy agar). After one day incubation, Mcfarland 0.5 turbidity was adjusted with saline using a direct object from single fallen colonies in agar plate [27]. According to Broth microdilution method; $50 \mu \mathrm{L}$ of Mueller Hinton Broth medium prepared for microorganisms were placed in all wells in sterile 96 well microplates. Then, the first well was prepared as $50 \mu \mathrm{L}$ from the solution of the prepared solution and double-level dilution was made to the first ten rows. Positive control, medium control and negative controls were prepared in the last two columns. Finally,
$10 \mu \mathrm{L}$ of bacteria were added to the wells containing antibiotics and were allowed to incubate. Spectrophotometric measurements were taken at 600 $\mathrm{nm}$ for bacteria before incubation and after incubation (t24 h) and at $415 \mathrm{~nm}$ for yeasts. In addition, dilutiondependent color changes of the substances were measured spectrophotometrically at the same wavelength ( 600 and $415 \mathrm{~nm}$ ) and subtracted from all results. Experiments were repeated 3 times and the percent inhibition values of mean values were calculated as follows:

$$
\% \text { Inhibition }=1-\left(\frac{\text { ODtest } t 24-t 0}{\text { oDcontrol } t 24-t 0}\right) \times 100
$$

The inhibition graph was plotted, the linear slope line $\mathrm{R}^{2}$ and the MIC (Minimum Inhibition Concentration; 99.9\% of the microorganisms killing agent concentration) were calculated $[28,29]$.

\subsection{In vitro cytotoxicity study (MTT assay)}

\subsubsection{Cell Culture}

A549, HT29 and MDA-MB-231 cells were obtained from the European Collection of Cell Cultures (ECACC, UK). The cells were cultured under standard conditions in Dulbecco's Modified Eagle Medium (DMEM), supplemented with $10 \%$ heat-inactivated fetal bovine serum (FBS), $100 \mathrm{U} / \mathrm{mL}$ of penicillin and $100 \mu \mathrm{g} / \mathrm{mL}$ of streptomycin were incubated in a humidified incubator set at $37{ }^{\circ} \mathrm{C}$ with $5 \% \mathrm{CO}_{2}$.

\subsubsection{Cytotoxicity Assay by MTT}

MDA-MB-231, HT29 and A549 cells were seeded in 96well plates at $1 \times 10^{4}$ viable cells per well. After $24 \mathrm{~h}$ of growth, the cells were treated with varying concentrations of Ecs and EcAgNPs (E. camaldulensis silver nanoparticles). The concentrations used for Ecs and EcAgNP were between 15.63 - $1000 \mu \mathrm{g} \mathrm{mL}-1$ and 3.13-200 $\mu \mathrm{g} \mathrm{mL} \mathrm{mL}^{-1}$, respectively. An equal amount of medium without Ecs and AgNP was added to untreated cells used as control. After continuous exposure for $24 \mathrm{~h}$ at $37{ }^{\circ} \mathrm{Cin}$ humidified $5 \% \mathrm{CO}_{2}$ atmosphere, $20 \mu \mathrm{l}$ per well MTT in phosphate-buffered saline (5 mg mL $\mathrm{m}^{-1}$ ) solution was added and incubated at $37{ }^{\circ} \mathrm{C}$ for $4 \mathrm{~h}$. Following incubation, medium was removed and $100 \mu \mathrm{LMSO}$ was added to dissolve the formazan precipitate formed by viable cells. This purple blue formazan dye was measured as optical density at $540 \mathrm{~nm}$ using a microplate reader (SpectraMax i3x). A graph was plotted between the concentrations of the Ecs and AgNP versus the percent viability. The concentration of the samples that inhibits growth of $50 \%$ of the cells IC $_{50}$ values) was calculated from graph. All assays were performed in three replicates per concentration level.

\subsubsection{Statistical analysis}

The SPSS-one way ANOVA, Tukey test were performed for between MICs recorded as mean \pm SEM (standard error of the mean). The experiment was repeated at 
least 3 times. Differences were considered significant at $\mathrm{p} \leq 0.05$.

\section{Result and Discussion}

In this study, we have synthesized nanoparticles from the extract of E. camaldulensis using green synthesis and studied their anticancer and antimicrobial activities. Generally, water extract of plant materials is being used to get the extract that is forwarded to the green synthesis. During the extraction, the water fraction is heated. In this study, we have performed a different approach without using any heat. First, we have obtained the methanol extract (1 week, three times) of the plant material at room temperature. The dried methanol extract was dissolved in water and filtered through 20 micron. The filtrate was forwarded to the synthesis of silver nanoparticles (AgNPs). The obtained AgNPs have shown higher anticancer (MDA-MB-231, HT29 and A549 cells) and antimicrobial (E. coli, P. aeruginosa, B. subtilis, $S$. aureus strains and $C$. albicans yeast) activities.

In the synthesis of nanoparticles, $\mathrm{NaBH}_{4}, \mathrm{NaOH}$ and similar strong bases are used to reduce the metals and increase the $\mathrm{pH}$. We have obtained better results in very short time $\left(75 \mathrm{~min}\right.$ ) to use only $\mathrm{NaHCO}_{3}$ to increase the $\mathrm{pH}$ (8). In a previous study on E. camaldulensis, AgNPs were prepared by heating the leaves at $80{ }^{\circ} \mathrm{C}$ in water [24]. Heating can cause the disintegration of chemical constituent. Another thing is that, very less organic compounds can be soluble in water. In this study, we have left the plant material in methanol to that maximum of the active constituents can be extracted.

\subsubsection{Visual observations and UV-visible spectroscopy}

AgNPs studies performed with plant extracts at acidic $\mathrm{pH}$, carried out under various physical conditions have significant effects on the morphology of nanoparticles. Literature shows that the synthesis of AgNPs in alkaline media has resulted comparatively smaller, homogenous and regular nanoparticle $[30,31,32,33,34,35]$.

The $\mathrm{pH}$ of the water fraction obtained from methanol extract (Ecs) was adjusted to be 8.0 with $1 \mathrm{M} \mathrm{NaHCO}_{3}$ (0.5-1.0 mL). $1 \mathrm{mM} \mathrm{AgNO}_{3}$ solution were mixed into the stated solution with a ratio of $1: 19$ (Solution: $\mathrm{AgNO}_{3}$ ). Initially, the mixture became dark yellow and later transformed into dark red. The mixture was stirred for 75 min under room temperature and the progress was observed by measuring absorbance by UV-visible spectrophotometer every $15 \mathrm{~min}$. In figure 1(A), sharp peaks obtained at $420 \mathrm{~nm}$ due to possible surface plasmon resonance effects of silver nanoparticles showed that nanoparticles were formed. Figure 1(B) shows the absorbance ( $\operatorname{lmax} 420 \mathrm{~nm}$ ) of AgNPs with the time. The graph reflected that nanoparticle synthesis slows down after the 30th min, while the synthesis completed in around $60 \mathrm{~min}$.
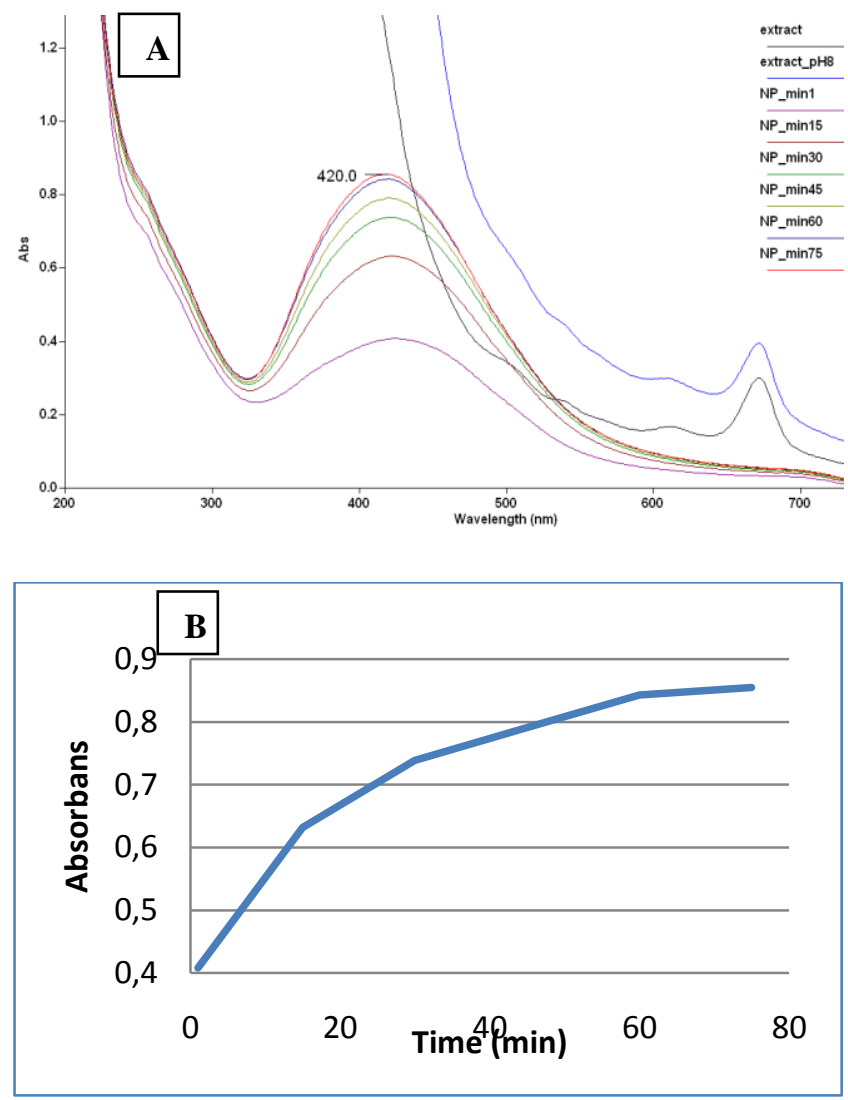

Figure 1. A) Absorbance (UV-visible) of E. camaldulensis leaves extract and AgNPs at various times (1-75 min);

B) progress of the AgNPs synthesis with time

\subsubsection{High resolution transmission electron microscope (HR-TEM) analysis}

Many physical parameters of the synthesized silver nanoparticles, such as size, shape and density, were observed by HR-TEM analysis with high resolution and amplification capacity. Fig. 2A show HR-TEM results from synthesized AgNPs. The synthesized AgNPs were determined to have varying sizes, homogeneous and spherical structure in the range of 3.7-29.6 nm (Fig. 2B). These results show that small and regular silver nanoparticles are formed in E. camaldulensis plant species mediated silver nanoparticle synthesis. 


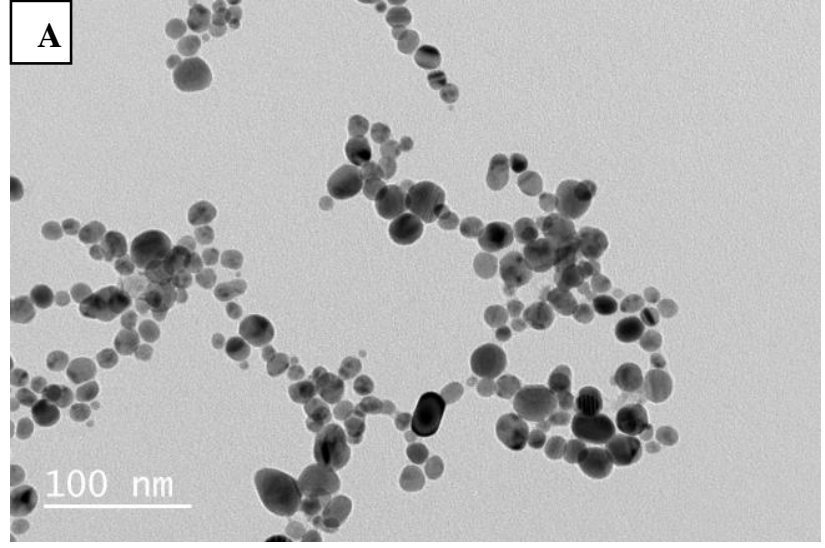

Figure 2. AgNPs mediated by Eucalyptus camaldulensis; (A) HR-TEM images, (B) Particle size distribution graph

\subsubsection{Field Emission Scanning Electron Microscope (FE-SEM) analysis}

In addition to the HR-TEM images, the morphology of the synthesized AgNPs was also monitored by SEM (Scanning Electron Microscopy). The results showed the presence of highly homogeneous, spherical nanoparticles similar to HR-TEM results (Fig. 3).

SEM image of the synthesized silver nanoparticles was found to be similar with TEM results. Silver nanoparticles were found to be spherical and uniformly conformed particles. The EDS analysis spectrum showed a specific signal for metallic Ag which was also obvious in the quant results chart with a $17.29 \%$ atomic percentage results.

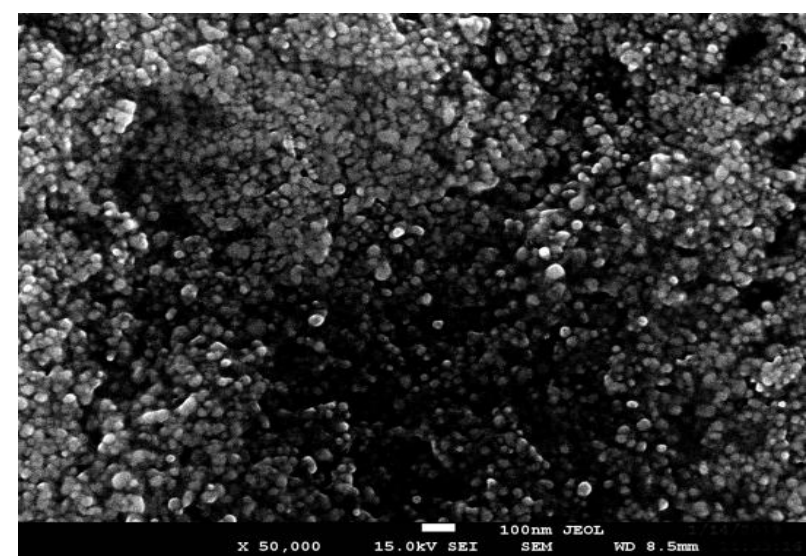

Figure 3. FE-SEM image obtained from Eucalyptus camaldulensis mediated AgNPs

Following SEM analysis, elemental analysis of the displayed nanoparticles was performed. For this purpose, the nanoparticles were confirmed to be Ag nanoparticles by the Energy Dispersion X-Ray Spectroscopy attachment integrated on the SEM device (Table 1).

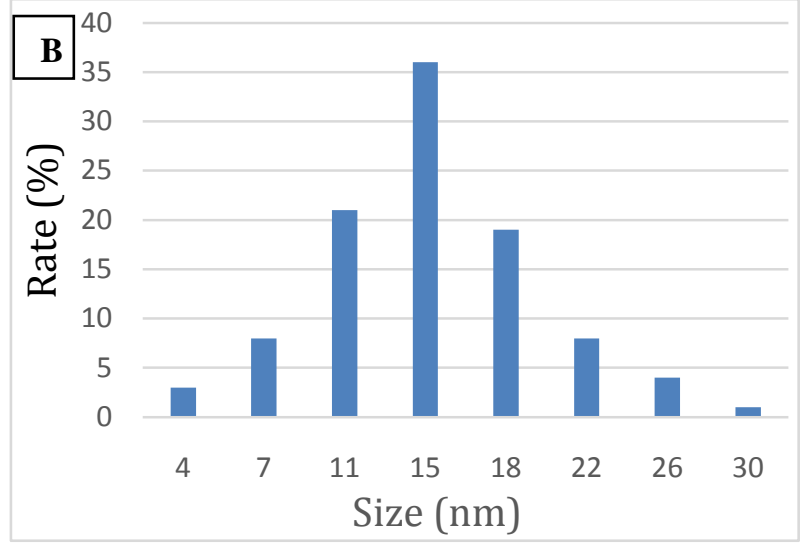

\begin{tabular}{ccc}
\multicolumn{3}{c}{ Table 1. Weight and atomic \% of various elements } \\
\hline Element & Weight (\%) & Atomic (\%) \\
\hline $\mathrm{C}$ & 26.57 & 66.39 \\
$\mathrm{O}$ & 6.56 & 12.31 \\
$\mathrm{Cl}$ & 4.74 & 4.01 \\
$\mathrm{Ag}$ & 62.13 & 17.29
\end{tabular}

In the spectrum taken by SEM-EDS, it is thought that the peaks of carbon (C) and oxygen (O) seen outside Ag are caused by the presence or formation of medium or stable molecules during the reactions for AgNP synthesis [36]. Similarly, chlorine $(\mathrm{Cl})$ ion is thought to result from the biological macromolecular structure of the plant extract used during synthesis. The peak of carbon (C) is due to the presence of a double-sided carbon band used for SEM sample preparation.

Numerous data TEM, SEM and SEM-EDS analysis of various plant-mediated silver nanoparticles are available $[4,7,9,10,11]$. When these data were evaluated, similar results were obtained with E. camaldulensis plant extract-mediated silver nanoparticles.

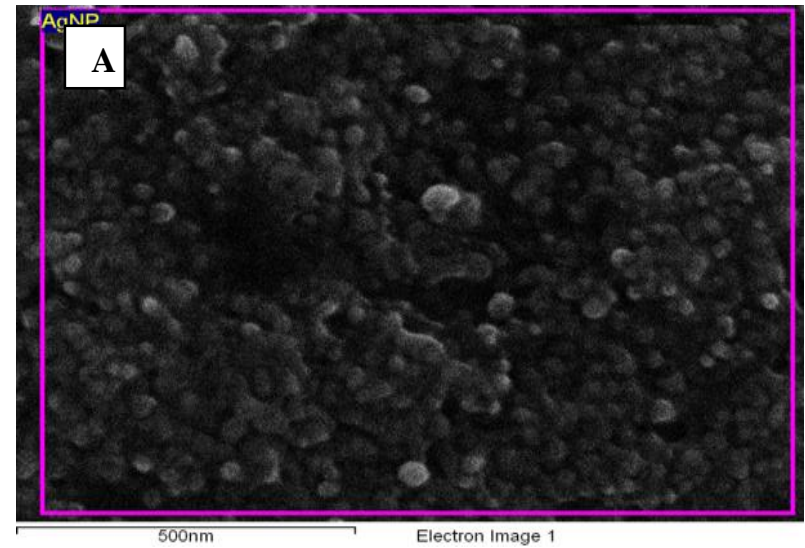




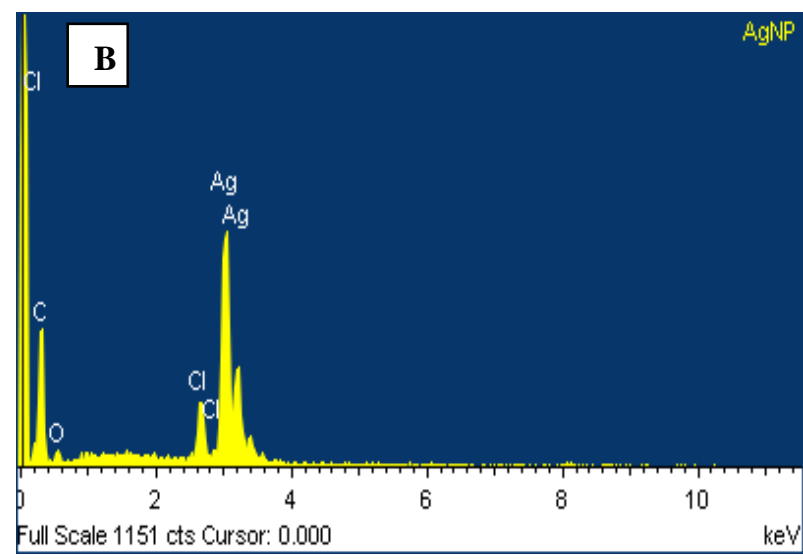

Figure 4. E. camaldulensis SEM-EDS results of leaf extract-mediated silver nanoparticles: A) SEM image of the silver nanoparticle and EDS scanning site; B) EDS spectrum of E. camaldulensis leaves extract mediated AgNPs

\subsubsection{Phenolic profile of aqueous fraction}

During the analysis, 30 phenolic compounds were screened and a 7-point calibration curve was generated for each compound. Using these data, determination and quantification of phenolic compounds in Table 2. of water fraction of E. camaldulensis plant was performed. Multiple reaction monitoring (MRM) chromatograms of gallic acid and quercetin, major phenolic compounds detected, are given in Fig. 5.

\subsubsection{Antimicrobial assay (MIC)}

The $24 \mathrm{~h}$ incubation of Ecs and biosynthesized EcAgNP with microorganisms was found to be statistically significant in terms of the resultant percent inhibition $(p<0.05)$ (Table 3). The EcAgNP extract were found to had highest antimicrobial activity against all pathogens compared with aqueous extract of E. camaldulensis. Ecs exhibited antimicrobial activity with MIC of between 16.2 and $129.3 \mathrm{mg} \mathrm{mL}^{-1}$ while EcAgNP had remarkable antimicrobial performance with MIC of between 6.31 and $14.65 \mu \mathrm{g} \mathrm{m}^{-1}$. In general, Gram positive bacteria were more sensitive than Gram negatives and yeasts in all treatments. The MICs were calculated as $6.58 \mu \mathrm{g} \mathrm{mL}^{-1}$ and $42.3 \mathrm{mg} \mathrm{mL}^{-1}$ for B. subtilis; as $6.31 \mu \mathrm{g} \mathrm{mL}^{-1}$ and 16.2 $\mathrm{mg} \mathrm{mL}^{-1}$ for $S$. aureus in EcAgNP and Ecs treatment, respectively.
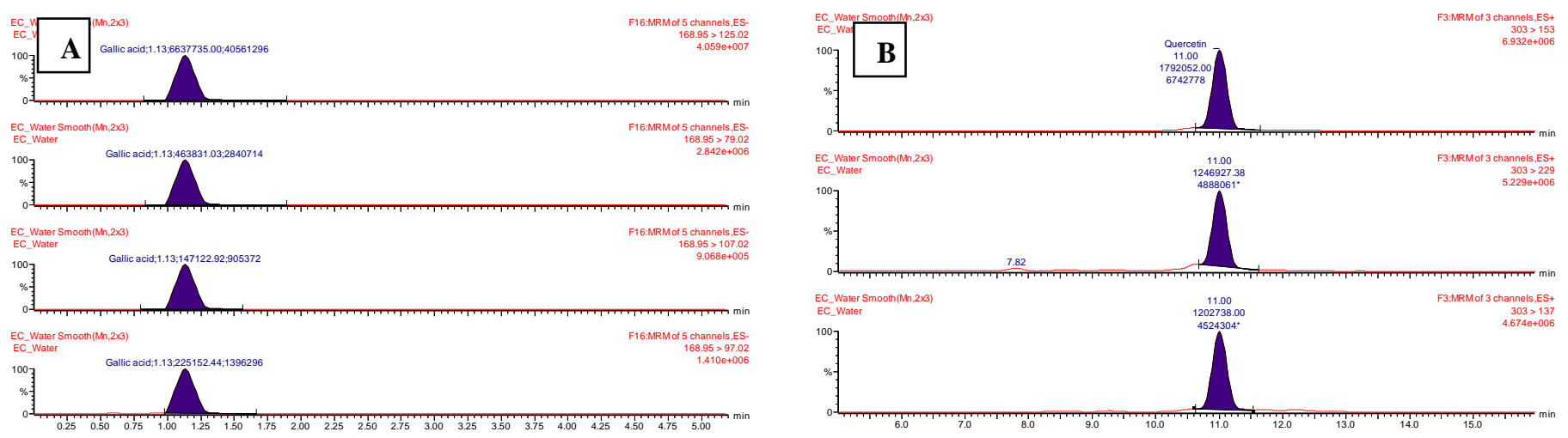

Figure 5. UPLC-MS/MS A) Gallic acid and B) Quercetin MRM chromatograms of E. camaldulensis water fraction
The most strongest MIC value for Ecs was $16.2 \mathrm{mg} \mathrm{mL}^{-1}$ against $S$. aureus, while the lowest were $75.4 \mathrm{mg} \mathrm{mL}^{-1}$ against E. coli. For C. albicans, EcAgNP $\left(6.29 \mu \mathrm{g} \mathrm{mL} \mathrm{m}^{-1}\right)$ was much more effective than $\mathrm{EcS}\left(129.3 \mathrm{mg} \mathrm{mL}^{-1}\right)$. The most important result of this study is that EcAgNP is more effective than ampicillin and fluconazole used as positive control on all bacterial strains (E. coli, $P$. aureginosa, B. subtilis and $S$. aureus) and C. albicans yeast.

For a long time, silver nanoparticles (AgNPs) were known for their antibacterial broad-spectrum effects. Many studies suggest that the main factors of their antimicrobial performance is the size of nanoparticles, method of synthesis, parameters and precursors used. For example, it was claimed that nanoparticles less than $10 \mathrm{~nm}$ penetrate the interior of bacterial cells, thereby increasing their bactericidal activity [37,38,39]. The MIC values of AgNP-sp (spherical) against E. coli, $P$. aeruginosa, $S$. aureus and B. subtilis were reported between 184 and $195 \mu \mathrm{g} \mathrm{mL}^{-1}$, while AgNR (rod-shaped) inhibited to the same pathogens with MIC of between 320 and $358 \mu \mathrm{g} \mathrm{mL} \mathrm{m}^{-1}$ [40]. In our study, spherical and AgNP incorporated with E. camaldulensis was as effective as an antibiotic. This may be due to the bioactive secondary metabolites of the plant $[18,19]$.

The strong antimicrobial potential of silver nanoparticles prepared with different Eucalyptus species was revealed. The antibacterial activity of nanoparticles prepared with aqueous and alcoholic extracts of Eucalyptus chapmaniana against $P$. aeruginosa, $S$. aureus and $C$. albicans were found to be rather high. The inhibition zones were above $10 \mathrm{~mm}$ by disc diffusion method, like antibiotics. However, in comparison with our study, MIC values were lower; MIC=between 0.8 and $1 \mathrm{~g} \mathrm{~mL}^{-1}$ [41]. In another study, MICs of nanoparticles of Eucalyptus globulus leaf extract

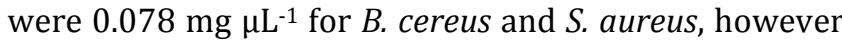
it was $0.19 \mu \mathrm{g} \mu \mathrm{l}^{-1}$ and $0.39 \mu \mathrm{g} \mu \mathrm{l}^{-1}$ for P. aeruginosa and E. coli, respectively [42]. In summarized, the antimicrobial activity of silver nanoparticles incorporated with E. camaldulensis increased against all microbes used. 
Table 3. MICs of the EcAgNP and Ecs against tested microbial strains by microdilution method.

\begin{tabular}{|c|c|c|c|}
\hline $\begin{array}{c}\text { Microorganism } \\
\text { /MIC }\end{array}$ & $\begin{array}{c}\text { Positive } \\
\text { control } \\
\left(\mu \mathrm{g} \mathrm{mL}^{-1}\right)\end{array}$ & $\begin{array}{c}\text { EcAgNP } \\
\left(\mu g \mathrm{~mL}^{-1}\right)\end{array}$ & $\begin{array}{c}\text { Ecs } \\
\left(\mathrm{mg} \mathrm{mL}^{-1}\right)\end{array}$ \\
\hline E. $\operatorname{coli}(-)$ & $16 \pm 0.06$ & $14.65^{*} \pm 0.36$ & $75.4^{*} \pm 10.03$ \\
\hline P. aureginosa (-) & $32 \pm 0.31$ & $7.12 \gamma \pm 0.06$ & $22.04 \gamma \pm 8.08$ \\
\hline B. subtilis (+) & $16 \pm 0.14$ & $6.58 \dagger \pm 0.09$ & $42.3 \dagger \pm 8.36$ \\
\hline S. aureus (+) & $32 \pm 1.1$ & $6.31 \neq \pm 0.17$ & $16.2 \neq \pm 11.3$ \\
\hline C. albicans & $64 \pm 1.4$ & $6.29 \# \pm 3.27$ & $129.3 \# \pm 8.1$ \\
\hline
\end{tabular}

For positive control, ampicillin (for bacteria) and fluconazole (for yeast) were used as positive control $\left(128 \mu \mathrm{g} \mathrm{mL}^{-1}\right)$. The average MICs were expressed with the standard deviation ( \pm ) and significance level ( $\mathrm{p} \leq$ $0.05)$ and $\dagger \ddagger \# \gamma$ : same signs differ statistically at the 0.05 level.

\subsubsection{In vitro MTT assay}

Anticancer activities of phytochemicals-mediated AgNPs are attracting increasing interest as novel agents because AgNPs are being used as carriers in targeted drug delivery systems. There is no report on the anticancer activity of both Ecs and EcAgNP in three human cancer cell lines human breast cancer MDA-MB231 cells, human adenocarcinoma colon HT29 cells and human non-small cell lung carcinoma A549 cells. In this study, we investigated the potential anticancer activities of both Ecs and EcAgNP in the MDA-MB-231, HT29 and A549 human cancer cell lines. These cancer cells were exposed to Ecs (15.63 - $1000 \mu \mathrm{g} \mathrm{mL} \mathrm{m}^{-1}$ ) and EcAgNP (3.13-200 $\mu \mathrm{g} \mathrm{mL}^{-1}$ ) for $24 \mathrm{~h}$ and the cytotoxicity was determined using MTT assay (Fig. 6-7). The calculated $\mathrm{IC}_{50}$ values are presented in Table 4 . and the corresponding concentration-effect curves are depicted in Fig. 6. EcAgNP exhibited markedly lower $\mathrm{IC}_{50}$ values in comparison with Ecs for all cell lines used. Hence, AgNP was found to have a higher cytotoxic effect than Ecs in all three cancer cell lines. These results demonstrate that the EcAgNP is able to inhibit tumor cell proliferation, and the effect was increased compared with Ecs. The results of the MTT assay indicate that EcAgNP exhibited similar IC $_{50}$ values for the three human tumor cell lines whereas Ecs exhibited higher cytotoxic activity particularly for the MDA-MB231 cell line. The present study showed that the sensitivity of MDA-MB-231 human breast cancer cell line for both Ecs and EcAgNP is higher than the other two cell lines.
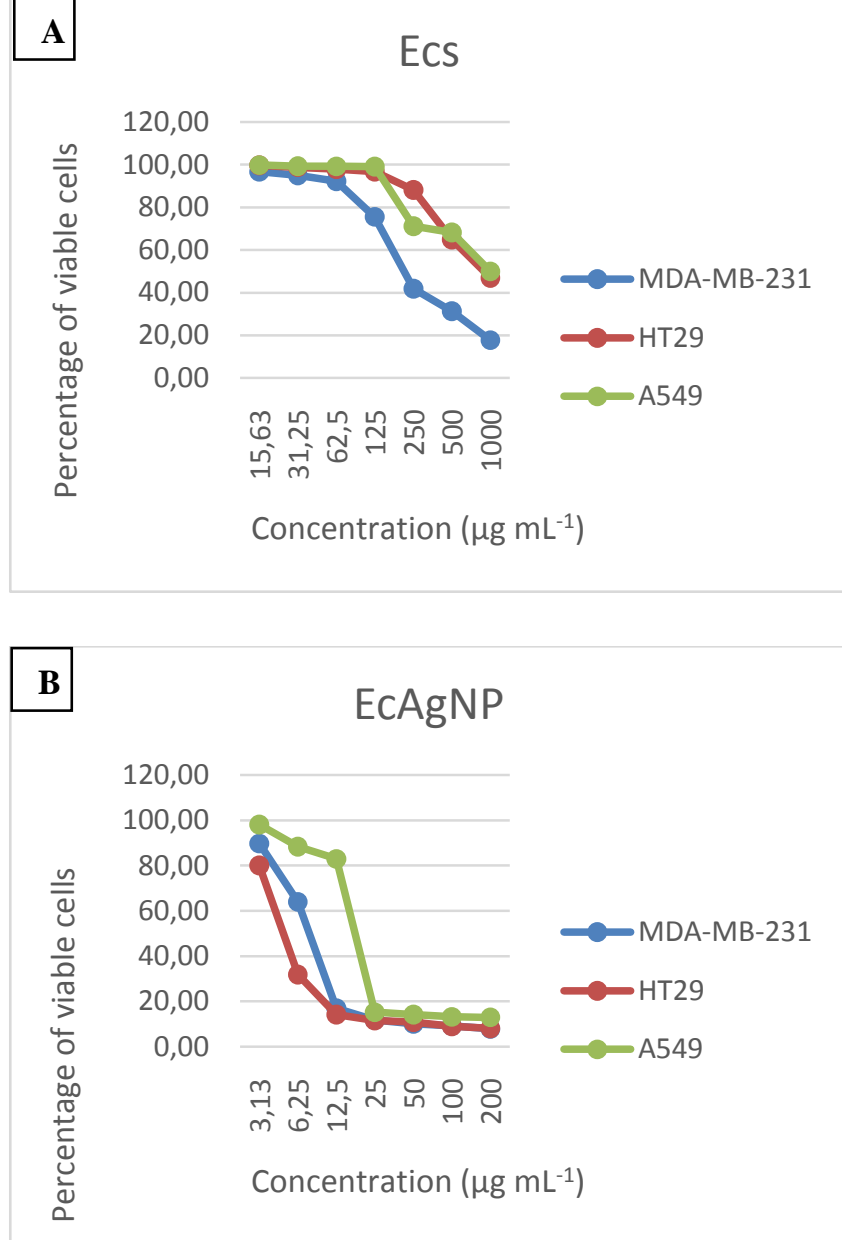

Figure 6. Concentration-effect curves of A) Ecs and B) EcAgNP in the MDA-MB-231, HT29 and A549 human cancer cell lines.

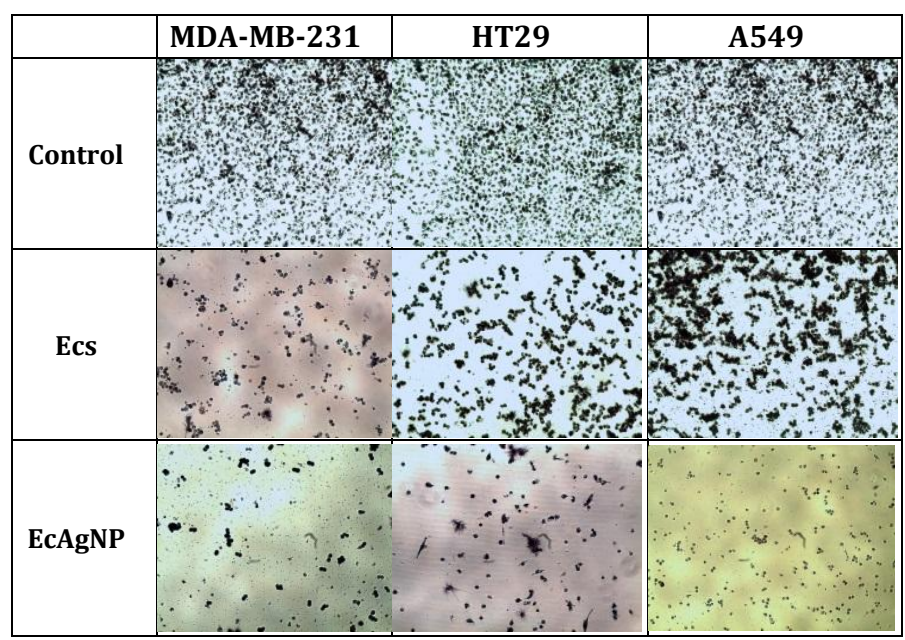

Figure 7. Formazan precipitate formed by viable cells at MTT assay of Ecs and EcAgNP in the MDA-MB-231, HT29 and A549 human cancer cell lines.

Table 4. Cytotoxicity of Ecs and EcAgNP in three human cancer cell lines.

Compound IC ${ }_{50}\left(\mu \mathrm{g} \mathrm{mL}^{-1}\right)$




\begin{tabular}{cccc}
\hline & MDA-MB-231 & HT29 & A549 \\
\cline { 2 - 4 } Ecs & $219.70 \pm 0.73$ & $916.24 \pm 0.67$ & $999.30 \pm 1.86$ \\
EcAgNP & $8.10 \pm 0.01$ & $5.08 \pm 0.01$ & $18.58 \pm 0.03$ \\
\hline
\end{tabular}

$\mathrm{IC}_{50}$ values represent the means \pm standard deviation of three parallel measurements $(\mathrm{p}<0.05)$.

\section{Conclusion}

AgNPs, green-synthesized from E. camaldulensis extract showed higher cytotoxicity than the sole extract in all three cancer cell lines i.e. MDA-MB-231, HT29 and A549. The synthesized nanoparticles were obtained homogeneously and spherically with an average size of about $15 \mathrm{~nm}$. AgNPs showed higher antimicrobial activity against $E$. coli, $P$. aeruginosa, B. subtilis, $S$. aureus bacterial strains and $C$. albicans yeast in disinfectants, textile coatings, antiseptic applications in areas such as medical, foods or cosmetics. In short, AgNPs showed both antimicrobial and anticancer potential. Further studies are needed to determine the exact mechanism behind the antimicrobial and anticancer activity at the molecular level.

\section{Acknowledgment}

This was supported by the Scientific Research Projects Coordination Unit of Muğla Sitkı Koçman University under Project number 17/228.

\section{References}

[1] Contescu, C.I., Putyera, K., Encyclopedia of Nanoscience and Nanotechnology Second Edition, Crop Science, 2009.

[2] Zahmakiran, M., Özkar, S., "Metal Nanoparticles in Liquid Phase Catalysis; From Recent Advances to Future Goals", Nanoscale, 3, 3462-3481, 2011.

[3] Ahmed, S., Ahmad, M., Swami, B.L., Ikram, S., A Review on Plants Extract Mediated Synthesis of Silver Nanoparticles for Antimicrobial Applications: A Green Expertise”, J. Adv. Res., 7, 17-28, 2016.

[4] Jadhav, K., Deore, S., Dhamecha, D., Hr, R., Jagwani, S., Jalalpure, S., Bohara, R., "Phytosynthesis of Silver Nanoparticles: Characterization, Biocompatibility Studies, and Anticancer Activity", ACS Biomater. Sci. Eng., 4, 892-899, 2018.

[5] Dhamecha, D., Jalalpure, S., Jadhav, K., Jagwani, S., Chavan, R., "Doxorubicin Loaded Gold Nanoparticles: Implication of Passive Targeting on Anticancer Efficacy", Pharmacol. Res., 113, 547-556, 2016.

[6] Ashraf, A., Sarfraz, R.A., Mahmood, A., Din, M. ud, "Chemical Composition and in vitro Antioxidant and Antitumor Activities of Eucalyptus camaldulensis Dehn. Leaves", Ind. Crops Prod., 74, 241-248, 2015.

[7] Mittal, J., Singh, A., Batra, A., Sharma, M.M., "Synthesis and Characterization of Silver Nanoparticles and Their Antimicrobial Efficacy", Part. Sci. Technol., 35, 338-345, 2017.

[8] Khan, Mujeeb, Khan, S.T., Khan, Merajuddin, Adil, S.F., Musarrat, J., Al-Khedhairy, A.A., Al-Warthan, A., Siddiqui, M.R.H., Alkhathlan, H.Z., "Antibacterial
Properties of Silver Nanoparticles Synthesized Using Pulicaria glutinosa Plant Extract as A Green Bioreductant", Int. J. Nanomedicine, 9, 3551-3565, 2014.

[9] Erci, F., Cakir-Koc, R., Isildak, I., "Green Synthesis of Silver Nanoparticles Using Thymbra spicata L. var. spicata (Zahter) Aqueous Leaf Extract and Evaluation of Their Morphology-Dependent Antibacterial and Cytotoxic Activity", Artif. Cells, Nanomed. Biotechnol., 46, 150-158, 2018.

[10] Ren, Y. yu, Yang, H., Wang, T., Wang, C., "Green Synthesis and Antimicrobial Activity of Monodisperse Silver Nanoparticles Synthesized Using Ginkgo biloba Leaf Extract", Phys. Lett. Sect. A Gen. At. Solid State Phys., 380, 3773-3777, 2016.

[11] Kanjikar, A.P., Hugar, A.L., Londonkar, R.L., "Characterization of Phyto-Nanoparticles From Ficus krishnae for Their Antibacterial and Anticancer Activities", Drug Dev. Ind. Pharm., 44, 377-384, 2018.

[12] Nakkala, J.R., Mata, R., Sadras, S.R., “Green Synthesized Nano Silver: Synthesis, Physicochemical Profiling, Antibacterial, Anticancer Activities and Biological in vivo Toxicity", J. Colloid Interface Sci., 499, 33-45, 2017.

[13] Kanipandian, N., Thirumurugan, R., "A Feasible Approach to Phyto-Mediated Synthesis of Silver Nanoparticles Using Industrial Crop Gossypium hirsutum (Cotton) Extract as Stabilizing Agent and Assessment of Its in vitro Biomedical Potential", Ind. Crops Prod., 55, 1-10, 2014.

[14] Ramar, M., Manikandan, B., Marimuthu, P.N., Raman, T., Mahalingam, A., Subramanian, P., Karthick, S., Munusamy, A., "Synthesis of Silver Nanoparticles Using Solanum Trilobatum Fruits Extract and Its Antibacterial, Cytotoxic Activity Against Human Breast Cancer Cell Line MCF 7", Spectrochim. Acta - Part A Mol. Biomol. Spectrosc, 140, 223-228, 2015.

[15] Elumalai, E.K., Prasad, T.N.V.K.V., Hemachandran, J., Viviyan Therasa, S., Thirumalai, T., David, E., "Extracellular Synthesis of Silver Nanoparticles Using Leaves of Euphorbia hirta and Their Antibacterial Activities", J. Pharm. Sci. Res., 2, 549$554,2010$.

[16] Kalishwaralal, K., Deepak, V., Ram Kumar Pandian, S.B., Kottaisamy, M., Barath ManiKanth, S., Kartikeyan, B., Gurunathan, S., "Biosynthesis of Silver and Gold Nanoparticles Using Brevibacterium casei", Colloids Surfaces B. Biointerfaces, 77, 257262, 2010.

[17] Adeniyi, B.A., Lawal, T.O. and Olaleye, S.B., "Antimicrobial and Gastroprotective Activities of Eucalyptus camaldulensis (Myrtaceae) Crude Extracts", J. Biol. Sci., 6, 1141-1145, 2006.

[18] Abubakar, E.M., "Antibacterial Potential of Crude Leaf Extracts of Eucalyptus camaldulensis Against Some Pathogenic Bacteria", African J. Plant Sci., 4, 202-209, 2010. 
[19] Ayepola, O., Adeniyi, B., "The Antibacterial Activity of Leaf Extracts of Eucalyptus camaldulensis (Myrtaceae)", J. Appl. Sci. Res., 4, 1410-1413, 2008.

[20] Luqman, S., Dwivedi, G.R., Darokar, M.P., Kalra, A., Khanuja, S.P.S., "Antimicrobial Activity of Eucalyptus citriodora Essential Oil", Int. J. Essent. Oil Ther., 2, 69-75, 2008.

[21] Wong-Paz, J.E., Contreras-Esquivel, J.C., RodríguezHerrera, R., Carrillo-Inungaray, M.L., López, L.I., Nevárez-Moorillón, G. V., Aguilar, C.N., “Total Phenolic Content, in vitro Antioxidant Activity and Chemical Composition of Plant Extracts from Semiarid Mexican Region", Asian Pac. J. Trop. Med., 8, 104-111, 2015.

[22] Singa, A.N., Ayoub, N., Al-Sayed, E., Martiskainen, O., Sinkkonen, J., Pihlaja, K., "Phenolic Constituents of Eucalyptus camaldulensis Dehnh, with Potential Antioxidant and Cytotoxic Activities", Rec. Nat. Prod., 5, 271-280, 2011.

[23] Cadahía, E., Conde, E., García-Vallejo, M.C., Fernández De Simón, B., "High Pressure Liquid Chromatographic Analysis of Polyphenols in Leaves of Eucalyptus camaldulensis, E. globulus and E. rudis: Proanthocyanidins, Ellagitannins and Flavonol Glycosides", Phytochem. Anal., 8, 78-83, 1997.

[24] Mohammed, A.E., "Green synthesis, antimicrobial and cytotoxic effects of silver nanoparticles mediated by Eucalyptus camaldulensis leaf extract" Asian Pac. J. Trop. Biomed., 5(5), 382-386, 2015.

[25] Kivrak, İ., "Analytical Methods Applied to Assess Chemical Composition, Nutritional Value and in vitro Bioactivities of Terfezia olbiensis and Terfezia claveryi from Turkey", Food Anal. Methods, 8, 12791293., 2015.

[26] Kıvrak, Ş., Kıvrak, İ., Karababa, E., “Analytical Evaluation of Phenolic Compounds and Minerals of Opuntia robusta J.C. Wendl. and Opuntia ficusbarbarica A. Berger", Int. J. Food Prop., 21, 244-256, 2018.

[27] Mcfarland, J., "An Instrument for Estimating The Number of Bacteria in Suspensions Used for Calculating the Opsonic Index and for Vaccines", Nephelom., 1176-1178, 1907.

[28] Erdogan Eliuz, E.A., Ayas, D., Goksen, G., "in vitro Phototoxicity and Antimicrobial Activity of Volatile Oil Obtained from Some Aromatic Plants", J. Essent. Oil-Bearing Plants, 20, 758-768, 2017.

[29] Patton, T., Barrett, J., Brennan, J., Moran, N., "Use of A Spectrophotometric Bioassay for Determination of Microbial Sensitivity to Manuka Honey", J. Microbiol. Methods, 64, 84-95, 2006.

[30] Borase, H.P., Patil, C.D., Salunkhe, R.B., Suryawanshi, R.K., Salunke, B.K., Patil, S. V., "Transformation of Aromatic Dyes Using Green Synthesized Silver Nanoparticles", Bioprocess Biosyst. Eng., 37, 1695-1705, 2014.

[31] Chathurdevi, G, Uma Gowrie, S., "Green Synthesis, Optimisation and Characterization of Silver Nano particles using Aqueous Bark Extract of Casuarina junghuhniana and its Bio Efficacy", Int. J. Pharm. Sci. Rev. Res., 39, 206-212, 2016.

[32] Gan, P.P., Li, S.F.Y., "Potential of Plant As A Biological Factory to Synthesize Gold and Silver Nanoparticles and Their Applications", Rev. Environ. Sci. Biotechnol., 11, 169-206, 2012.

[33] Mishra, A., Kaushik, N.K., Sardar, M., Sahal, D., "Evaluation of Antiplasmodial Activity of Green Synthesized Silver Nanoparticles”, Colloids Surfaces B Biointerfaces, 111, 713-718, 2013.

[34] Velmurugan, P., Anbalagan, K., Manosathyadevan, M., Lee, K.J., Cho, M., Lee, S.M., Park, J.H., Oh, S.G., Bang, K.S., Oh, B.T., "Green Synthesis of Silver and Gold Nanoparticles Using Zingiber officinale Root Extract and Antibacterial Activity of Silver Nanoparticles Against Food Pathogens", Bioprocess Biosyst. Eng., 37, 1935-1943, 2014.

[35] Xia, Q.H., Ma, Y.J., Wang, J.W., "Biosynthesis of Silver Nanoparticles Using Taxus yunnanensis callus and Their Antibacterial Activity and Cytotoxicity In Human Cancer Cells", Nanomaterials, 6, 2016.

[36] Baygar, T., Ugur, A., "Biosynthesis of Silver Nanoparticles by Streptomyces griseorubens Isolated from Soil and Their Antioxidant Activity", IET Nanobiotechnology, 11, 286-291, 2017.

[37] Cho, K.H., Park, J.E., Osaka, T., Park, S.G., "The Study of Antimicrobial Activity and Preservative Effects of Nanosilver Ingredient", Electrochim. Acta, 51, 956960, 2005.

[38] Khalandi, B., Asadi, N., Milani, M., Davaran, S., Abadi, A.J.N., Abasi, E., Akbarzadeh, A., "A Review on Potential Role of Silver Nanoparticles and Possible Mechanisms of Their Actions on Bacteria", Drug Res. (Stuttg)., 67, 70-76, 2017.

[39] Niño-Martínez, N., Salas Orozco, M.F., MartínezCastañón, G.A., Torres Méndez, F., Ruiz, F., "Molecular Mechanisms of Bacterial Resistance to Metal and Metal Oxide Nanoparticles", Int. J. Mol. Sci., 20, 2019.

[40] Sütterlin, S., Tano, E., Bergsten, A., Tallberg, A.B., Melhus, A., "Effects of Silver-Based Wound Dressings on the Bacterial Flora In Chronic Leg Ulcers and Its Susceptibility in vitro to Silver", Acta Derm. Venereol., 92, 34-39, 2012.

[41] Hussein, N.N., "Antihaemolytic and Antimicrobial Activity of Three Types of Local Plants", Biochem. Cell. Arch., 18, 1721-1726, 2019.

[42] Thakur, K., Bala, I., "Evaluation of Effectiveness of Biologically Synthesized Silver Nanoparticles of Eucalyptus globules Leaf Extract against Pathogenic and Acne-inducing Bacteria", J. Nanomed. Nanotechnol., 08, 2017. 
Table 2. Phytochemical composition (phenolic profile) identified in water fraction of Eucalyptus camaldulensis leaves by UPLC-MS/MS (ng mL ${ }^{-1} \pm$ standard deviation).

\begin{tabular}{|c|c|c|c|c|c|c|}
\hline Number & Compound & $\begin{array}{c}\text { RT } \\
(\mathrm{min})\end{array}$ & $\begin{array}{c}\text { Ecs } \\
\text { Concentration } \\
\text { (ppb) }\end{array}$ & $\begin{array}{l}\text { Ionization } \\
\text { Mode }\end{array}$ & $\begin{array}{c}\text { Recovery } \\
(\%)\end{array}$ & $\mathbf{R}^{2}$ \\
\hline 1 & Pyrogallol & 0.97 & $0.06 \pm 0.02$ & ESI $(-)$ & $99.8-101.3$ & 0.9328 \\
\hline 2 & Gallic acid & 1.13 & $20.26 \pm 0.10$ & ESI $(-)$ & $98.8-100.2$ & 0.9580 \\
\hline 3 & Homogentisic acid & 1.47 & ND & ESI $(-)$ & $92.3-94.5$ & 0.9991 \\
\hline 4 & Protocatechuic acid & 1.85 & $1.49 \pm 0.05$ & ESI $(-)$ & 99.7-101.5 & 0.9730 \\
\hline 5 & Gentisic acid & 1.85 & ND & ESI $(-)$ & 98.0-100.1 & 0.9994 \\
\hline 6 & Pyrocatechol & 2.38 & $0.13 \pm 0.02$ & ESI $(-)$ & $100.2-104.2$ & 0.9854 \\
\hline 7 & Galanthamine & 2.68 & ND & ESI $(+)$ & 91.3-99.8 & 0.9506 \\
\hline 8 & p-Hydroxy benzoic acid & 2.75 & $0.25 \pm 0.03$ & ESI (-) & $86.5-99.2$ & 0.9605 \\
\hline 9 & 3,4-Dihydroxybenzaldehyde & 2.76 & $0.36 \pm 0.04$ & ESI $(-)$ & 93.0-98.7 & 0.9840 \\
\hline 10 & Catechin hydrate & 3.45 & ND & ESI $(-)$ & $97.6-100.5$ & 0.9383 \\
\hline 11 & Vanillic acid & 3.61 & ND & ESI $(-)$ & $97.0-99.6$ & 0.9667 \\
\hline 12 & Caffeic acid & 3.65 & ND & ESI $(-)$ & 88.3-99.4 & 0.9798 \\
\hline 13 & Syringic acid & 4.11 & ND & ESI $(-)$ & $85.9-94.5$ & 0.9610 \\
\hline 14 & Vanillin & 4.50 & $0.06 \pm 0.01$ & ESI $(-)$ & $92.4-96.5$ & 0.9976 \\
\hline 15 & $p$-Coumaric acid & 4.65 & $0.31 \pm 0.02$ & ESI $(-)$ & 89.4-101.2 & 0.9328 \\
\hline 16 & Ferulic acid & 5.36 & ND & ESI $(-)$ & $87.0-96.3$ & 0.9176 \\
\hline 17 & Epicatechin & 5.50 & ND & ESI $(-)$ & $96.9-99.9$ & 0.9790 \\
\hline 18 & Catechin gallate & 5.91 & ND & ESI $(-)$ & $97.2-100.2$ & 0.9501 \\
\hline 19 & Rutin & 5.95 & $7.84 \pm 0.10$ & ESI $(-)$ & 98.1-102.5 & 0.9986 \\
\hline 20 & trans-2-Hydroxy cinnamic acid & 6.32 & ND & ESI $(-)$ & $98.7-99.9$ & 0.9250 \\
\hline 21 & Myricetin & 6.83 & ND & ESI $(-)$ & $94.5-100.4$ & 0.9426 \\
\hline 22 & Resveratrol & 7.23 & ND & ESI $(-)$ & 86.1-107.0 & 0.9973 \\
\hline 23 & trans-Cinnamic acid & 8.19 & ND & ESI $(-)$ & $93.8-99.0$ & 0.9500 \\
\hline 24 & Luteolin & 8.27 & ND & ESI $(-)$ & $96.2-99.7$ & 0.9995 \\
\hline 25 & Quercetin & 8.29 & $12.4 \pm 0.08$ & ESI $(+)$ & 85.1-102.4 & 0.9980 \\
\hline 26 & Naringenin & 9.17 & ND & ESI (-) & $95.8-99.0$ & 0.9504 \\
\hline 27 & Genistein & 9.22 & ND & ESI (+) & $82.4-89.5$ & 0.9392 \\
\hline 28 & Apigenin & 9.35 & ND & ESI (-) & $100.2-106.4$ & 0.9199 \\
\hline 29 & Kaempferol & 9.50 & ND & ESI (-) & 93.3-95.9 & 0.9744 \\
\hline 30 & Hesperetin & 9.71 & $0.02 \pm 0.00$ & ESI $(-)$ & $91.2-95.4$ & 0.9912 \\
\hline
\end{tabular}

